\title{
NON-AGENDA
}

With the view of causing an increase to take place in the mass of national wealth, or with a view to increase of the means either of subsistence or enjoyment, without some special reason, the general rule is, that nothing ought to be done or attempted by government. The motto, or watchword of government, on these occasions, ought to be - Be quiet... Whatever measures, therefore, cannot be justified as exceptions to that rule, may be considered as non-agenda on the part of government.

- Jeremy Bentham (c.1801)

\section{Writing About Somewhere Else}

\section{Michael Warby}

7 he publication of the final report of the McClure Committee of inquiry into the Australian welfare system, and of a collection essays edited by Peter Saunders by the Institute of Family Studies, led to an outbreak of newspaper commentary discussing how much welfare dependency has grown and what this means for public policy.

Yet many academic and other commentators tell us that we live in an age of shrinking government. For example, Professor Ron McCallum, the Blake Dawson Waldron Professor of Law at the University of Sydney, said in his 1997 Whitlam Lecture that:

They [the economic reformers] ... advocated labour market flexibility at a time when federal and State governments were shrinking their public sectors and reining in their spending. Governments bought the idea that greater labour market flexibility would limit unemployment. At this time, the social capacity of governments to cope with welfare programs and payments was diminishing, but if it would limit unemployment then deregulation was worth a try.

In her 1995 Boyer Lectures for the ABC, Eva Cox claimed that there has been a diminution of 'social capital' due to cutbacks in government expenditure and activity while Stuart Macintyre (1999a:270), Dean of the Faculty of Arts and

Michael Warby is a Fellow of the Institute of Public Affairs. 
Ernest Scott Professor of Histary of Melboume University, in his recently published Concise History of Aust:alia says that:

The left hand of the state - he social workers, teachers and health workers - was marginalised by the right hamd of the state - the treasury and finance departments - that withdrew their resources.

Similarly, in Australia at Vork, the key monograph from the Australian Centre for Industrial Relations Research and Training (ACIRRT, 1999:16) at Sydney University, we are told:

The slow dismantling of the welfare state which became the norm from the late 1970s onward: growing restrictioms on eligibility for benefits, shelving of social reforms, winding back of public housing, health, education and transport.

It is not clear where these commentators are writing about, but it is not the Australia the rest of us actually live in. It is true that there has been considerable privatisation, and the size of the state as measured by total government outlays, including government business enterprises (GBEs), as a percentage of GDP actually peaked in 1985-86 (Warby and Nahain, 1998). Similarly, the public sector's share of employment rose from 19.8 per cent in 1970-71 to 25.8 per cent in 1983-84. Privatisation then saw it fall to 17.3 perr cent by $1997-98$, yet the increase in welfare dependency has actually seen the proportion of the adult population dependent on the state for its income increase markedly to 1983 and remain roughly steady since then (Warby 1998:53).

\section{Figure 1: Growth in General Government Outlays per Resident} since $1982-83(\%)$

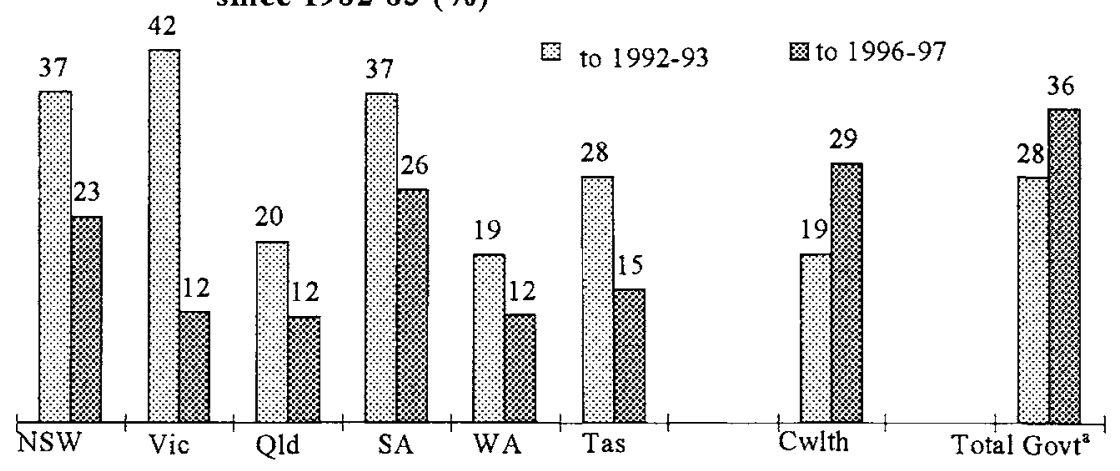

Note a: As State grants make up a significant proportion of Commonwealth outlays, and because Territories are not included in the Figure, the proportionate change in Total Government outlays is not a simple weighted sum of the illustrated components.

Source: ABS Australian Demographic Statistics, Australia; National Income, Expenditure and Product; Government Financial Estimates, Australia, various. 
The share of GDP of general government provision of goods and services (either directly or through prowision by non-rofit institutions) plus personal transfers has also increased markedly since 1972.73 and even since 1982-83.

Table 1: General Government, Current Outlays and Revenue

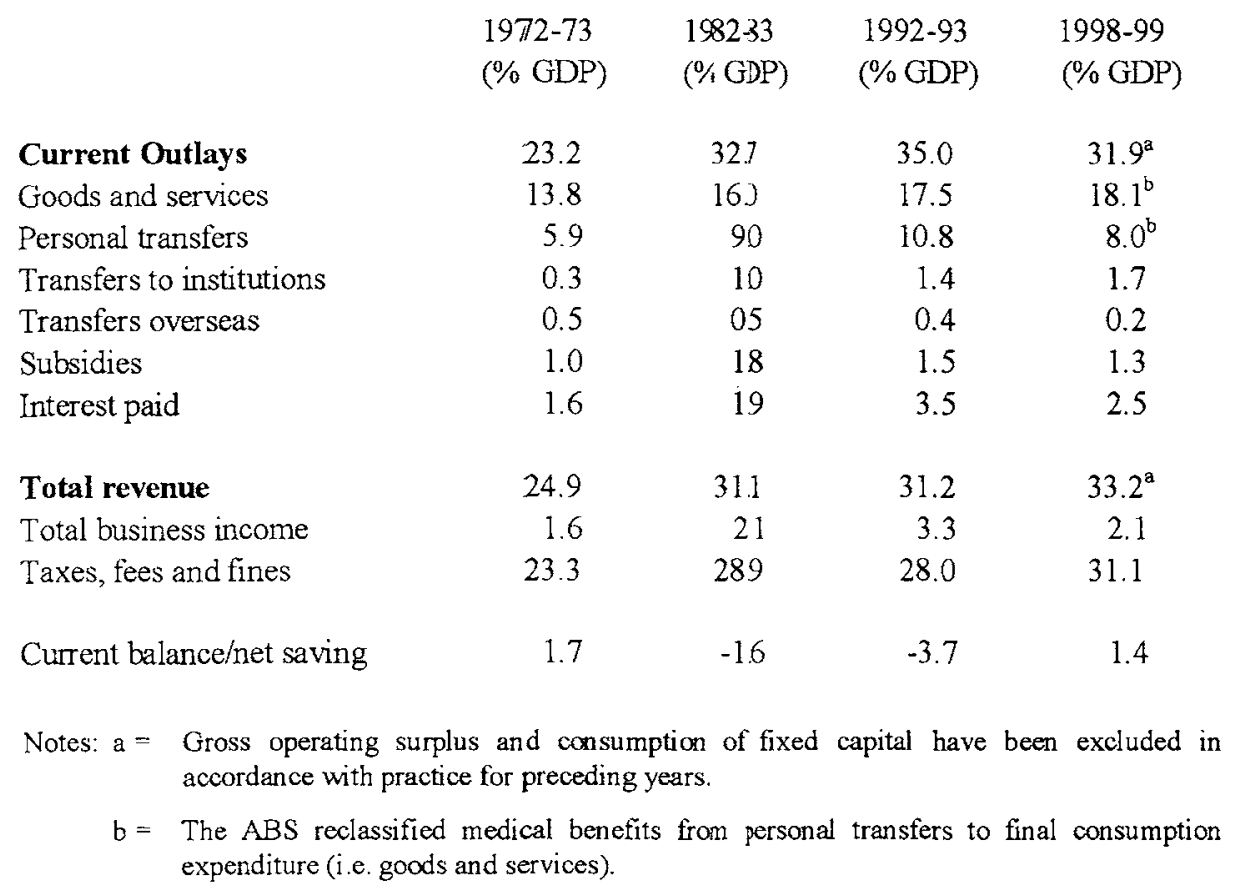

Source: ABS Australian System of National Accounts; National Income, Expenditure and Product, various.

Proportionately, the largest winners from increased government largesse have been non-profit organisations such as private schools, hospitals and various welfare and other agencies, who now receive almost $\$ 10$ billion in current transfers annually from the general government sector (or 1.7 per cent of GDP). The huge growth in transfers to non-government organisations (NGOs) - adjusted for inflation, the total has grown twelvefold since 1972-73 - has created a plethora of 'independent' voices with considerable resources to deploy- in 1995-96, nonprofit community services organisations spent $\$ 39 \mathrm{~m}$ on social action and group advocacy and another $\$ 39 \mathrm{~m}$ on social planning and policy development - sums which dwarf the annual budgets of all private sector think tanks combined and which do not include expenditure by pure advocacy groups (ABS Community Services, Australia, 1995-96). They have an interest in spruiking up government expenditure by loudly claiming the existence of worsening social problems and denouncing government 'cutbacks' and rarely get called on such claims by 
journalists. This creates 'noise' in public delbate which no doubt helps convey incorrect impressions. But the appropriate rrole of scholars is to check such erroneous impressions, not to legitimate them.

Part of the problem may simply be academics wandering outside their area of expertise. One particularly notable change is the increased revenues that government has been receiving fron GBEs, despite considerable privitisation. Dividends from GBEs have gone from a derisony 0.12 per cent of GDP in 1972-73 and 0.43 in 1982-83 to 1.4 per cent of GDP in 1998-99 (ABS Australian System of National Accounts, various). This greatly imcreased return to taxpayers from GBEs represents the successful achievement of a prime aim of the economc reform program. Yet, at one conference on economic reform, University of Sydney Professor of Sociology Michael Pusey quoted figures on improved perfornance by GBEs as a refutation of "economic rationalism" apparently blissfully unaware that the GBE sector received more systematic attention from the reformers than any other, and the figures he was quoting were in fact indicators of the success of the reform agenda. On the other hand, that subsidies' share of GDP has declined since $1982-83$, but is still higher than in $1972-73$ - in part due to adjustment payments — indicates the complexities involved.

\section{The Drivers of Economic Reform}

The Whitlam Government triggered a continuing expansion of the Australian welfare state. The collapse in general government saving due to the resultant tendency for expenditure on the Australian welfare state to increase faster than revenues indicates the fiscal pressure this generated (Table 1). (The recovery in general government saving since the recession of the early 1990 s has been as much from revenues increasing faster than GDP as it has from a trimming of outlays as a share of GDP.)

This fiscal pressure has been a major, arguably the major driver, of economic reform. As fiscal pressure mounted, seeking increased revenues from increased economic efficiency became more urgent. Political tolerance for mendicant industries waned. The role of industry increasingly became to generate the tax and other revenues to sustain the growing welfare state. High-cost GBE's could no longer be allowed to provide infrastructure or other services inefficiently. As expenditure and debt liabilities mounted - note the increase in interest paid's share of GDP (Table 1) - the reduction of such liabilities through asset sales became far more attractive, particularly after various disasters in government (mis)management, such as Tricontinental in Victoria, the State Bank in South Australia, government tourist ventures in the Northern Territory and WA Inc. The result was the familiar range of micro-economic reform - corporatisation and privatisation (to increase income from GBEs, reduce debt, and increase efficiency) and deregulation and reductions in trade barriers (to increase economic efficiency).

Economic reform was the pragmatic response of policy makers to pressure unleashed by this after various alternative strategies - the Fraser Government's 
strategy of relying on resources booms to avid hard decisions; the Cain-Kirner strategy of government as pump primer; the various aforementioned failures in attempts to use GBEs and public-private prtnerships as drivers of economic activity - failed disastrously. There had to b powerful forces driving politicians, State andFederal and from both sidess of politis, to embrace a reform agenda many aspects of which were not inherently popular But to actually acknowledge that pragmatism, the underlying pressures and the filure of alternatives, is to take large steps towards legitimating the econormic reforms.

Instead, we get bizarre and/or trivialisng 'explanations'. In the bizarre category is Reader in Sociology at La TrobeUniversity John Carroll tracing the reforms to the effect of the French Revolutio in making a program of reform a basis for political legitimacy (Carrolll, 1999). A more common alternative - seen in Eva Cox and Jenny Stewart - is to charactrise economic liberalisation as some Anglo-Saxon delusion created by economists. A Commonwealth Treasury seminar in about 1994 given by David Henderson wasrendered particularly amusing by $\mathrm{Dr}$ Stewart suggesting economic liberalisation wasjust an Anglo-Saxon fad and having Henderson, in his understated British way, demolishing this silly proposition by citing eccnomic liberalisations across OECD cuntries and beyond.

That the $\mathrm{ABC}$ and Universities - as pime examples of regressive middle class welfare - are the natural pressure poins for fiscal stress (thus, funding per university student has fallen 18.8 per cent fom 1983 to 1999) ${ }^{1}$ just adds to the irony of an expanding welfare state driving exonomic reform, given that both are also bastions of welfarist sentiment and hostility to economic liberalism. Widespread academic disenchantment with economic reform has presumably been aided by the universities having experienced 'reform' in the guise of a levelling, Philistine managerialism. Then again, educaton provides an excellent example of how having government as both regulator and main producer tends to corrupt both functions (witness the lack of reliable information on the performance of public education systems).

To claim that the state has withdrawn from many areas of social policy (Macintyre, 1999a:271) is also to describe sone fictional Australia. While the state has withdrawn from some direct provision, there is no area of social policy where the state is not more active now than 25 years ago, even though the focus may have changed (for example, it used to protect Arglo-Celtic identity, now it supports indigenous and other non-Anglo identity). The collapse in the rhetorical pretensions of government is mistaken for its actual retreat: in reality, as Nobel Laureate James Buchanan says, socialism may be dead but Leriathan lives on (Buchanan, 1990).

The level of increase of government activity is even more striking if one looks at changes in real expenditure per head. Governments deploy considerably more resources per Australian than they did in 1972-73, or even than they did at the beginning of the reform period in 1982-83. General government current outlays (on

See, Norton (2000). 
a national account basis) have more than douibled since 1972-73, they have increased almost 40 per cent sine 1982-83.

Table 2: Government, Current Outlays amd Revenue Per Resident

\begin{tabular}{|c|c|c|c|c|}
\hline & $\begin{array}{l}1972-73 \\
(\$ 96-97)\end{array}$ & $\begin{array}{l}1982-833 \\
(\$ 96-97)\end{array}$ & $\begin{array}{l}1992-93 \\
(\$ 96-97)\end{array}$ & $\begin{array}{r}1998-99 \\
(\$ 96-97)\end{array}$ \\
\hline Current Outlays & 7,342 & 7,049 & 8,997 & $9,827^{\mathrm{a}}$ \\
\hline Goods and services & 2,576 & 3,448 & 4,502 & $5,597^{\mathrm{b}}$ \\
\hline Personal transfers & 1,107 & 1,946 & 2,783 & $2,468^{b}$ \\
\hline Transfers to institutions & 61 & 219 & 348 & 517 \\
\hline Transfers overseas & 103 & 108 & 96 & 68 \\
\hline Subsidies & 189 & 383 & 382 & 399 \\
\hline Interest paid & 306 & 410 & 895 & 778 \\
\hline Total revenue & 4,667 & 6,696 & 8,040 & $10,245^{\mathrm{a}}$ \\
\hline Total business income & 295 & 463 & 844 & 658 \\
\hline Taxes, fees and fines & 4,371 & 6,233 & 7,196 & 9,586 \\
\hline Current balance/net saving & 325 & -353 & -957 & 418 \\
\hline $\begin{aligned} \text { Notes: } \mathrm{a}= & \text { Gross operating } \\
& \text { accordance with }\end{aligned}$ & $\begin{array}{l}\text { and consu } \\
\text { for preced }\end{array}$ & $\begin{array}{l}\text { of of fixed } \\
\text { ears. }\end{array}$ & al have bc & luded in \\
\hline $\begin{aligned} b= & \text { Medical benefits } \\
& \text { final consumptic }\end{aligned}$ & $y$ inclu & sonal tr & & $d$ as \\
\hline
\end{tabular}

Source: ABS Australian Demographic Statistics, Australia; National Income, Expenditure and Product; Government Financial Estimates, Australia, various.

A common claim about the history of a fictional Australia is that the Fraser Government presided over some great cutback in government activity as part of some post-Whitlam shrinkage in government (Macintyre, 1999a:240 and 265).

Under Fraser, Commonwealth expenditure per head fell in real terms in only two years (1978/79 and 1979/80), and then only by derisory proportions (0.1 and 0.3 per cent). By contrast, expenditure per head fell in real terms in three years under Hawke (1986/87, 1987/88 and 1988/89) and by more considerable proportions $(0.5,4.1$ and 6.5 per cent) (Figure 2 ).

The Commonwealth budget sector has shown a generally upward trend as a percentage of GDP until 1984/85, and strongly upward trend in terms of expenditure per Australian since. Overall, the general government sector, as a percentage of GDP, has increased dramatically from the time of the Whitlam Government. Given the tendency of GDP to increase, a drop in the government share of GDP (when this has occurred) is not a sign of shrinkage: it has normally been merely a sign of government failing to grow as fast as the rest of the economy. 
Even over the reform period the range of public support has increased, both in groups (for example, students, scole parents, low-ncome working families) and in support mechanisms (for examples, health and childcare).

This fictionalisation of the Fraser Govenment's record has since been repeated about the Howard Gowernment allegedy taking an axe to government expenditure, particularly welfare texpenditure. In the real Australia, Prime Minister John Howard presides over a lhigher level of Commonwealth expenditure per Australian than any previous PM: twice that under the last McMahon budget, more than 50 per cent higher than the last Whitlam bulget, a third higher than the last Fraser budget, 16 per cent higher than the last Haxke budget, though a mere 3 per cent higher than the last Keating budget. The increase in revenues per head has been even more striking, being aliso twice that of tie last McMahon budget, but 70 per cent higher than the last Whitllam budget, almost 50 per cent higher than the last Fraser budget, more than a third thigher than the last Hawke budget and 16 per cent higher than the last Keating lbudget. The fscal rectitude of the Howard Government has been primarily purchased, not through expenditure cuts, but via revenue increases and reductions; in the growth of spending, with expenditure per head dropping in only one year ((1997-98). Even then, the 2.9 per cent drop per head was more than wiped out by the 5.5 per cent increase in expenditure per head the following year (Figure 2).

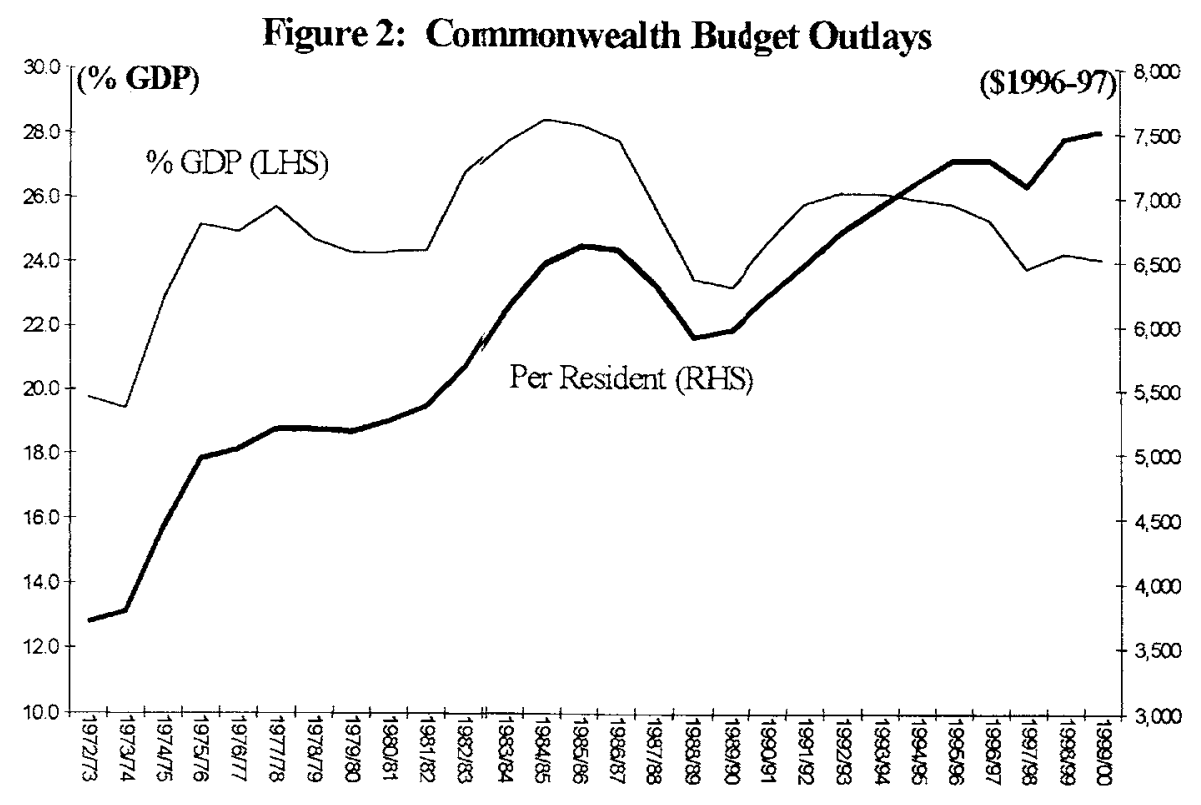

Source: Commonwealth Budget Papers, ABS Australian Demographic Statistics, Australia; National Income, Expenditure and Product; various. 
tnother common claim is that Australia has become a more unequal society (Maintyre, 1999a:245). In the real Australia, welfare provision increased and the Hawte-Keating Governments made strenuous attempts to target welfare and 'social wage policy to counteract the increased dispersion of wages: an attempt that, as the vork of Professor Ann Harding shows, was effective. Once the effect of govenment taxing and spending is taken into effect, income inequality has not changed. One would have to have remarkably low confidence in the competence of Austalian governments to believe that government spending on health, education and velfare can go from about 18 per cent of GDP in 1982-83 to over 20 per cent of GJP in 1996-97, with an 80 per cent increase in total expenditure and a 50 per cent ncrease in expenditure per Australian and have income inequality after taxesand-ransfers increase (ABS Australian Demographic Statistics, Australia; National Incone, Expenditure and Product; various). If that had been the case, the argument for government welfare would indeed have been bereft. Moreover, the poor got richer (Harding, 1997, various, especially page 19).

Figure 3: Commonwealth Budget Revenue

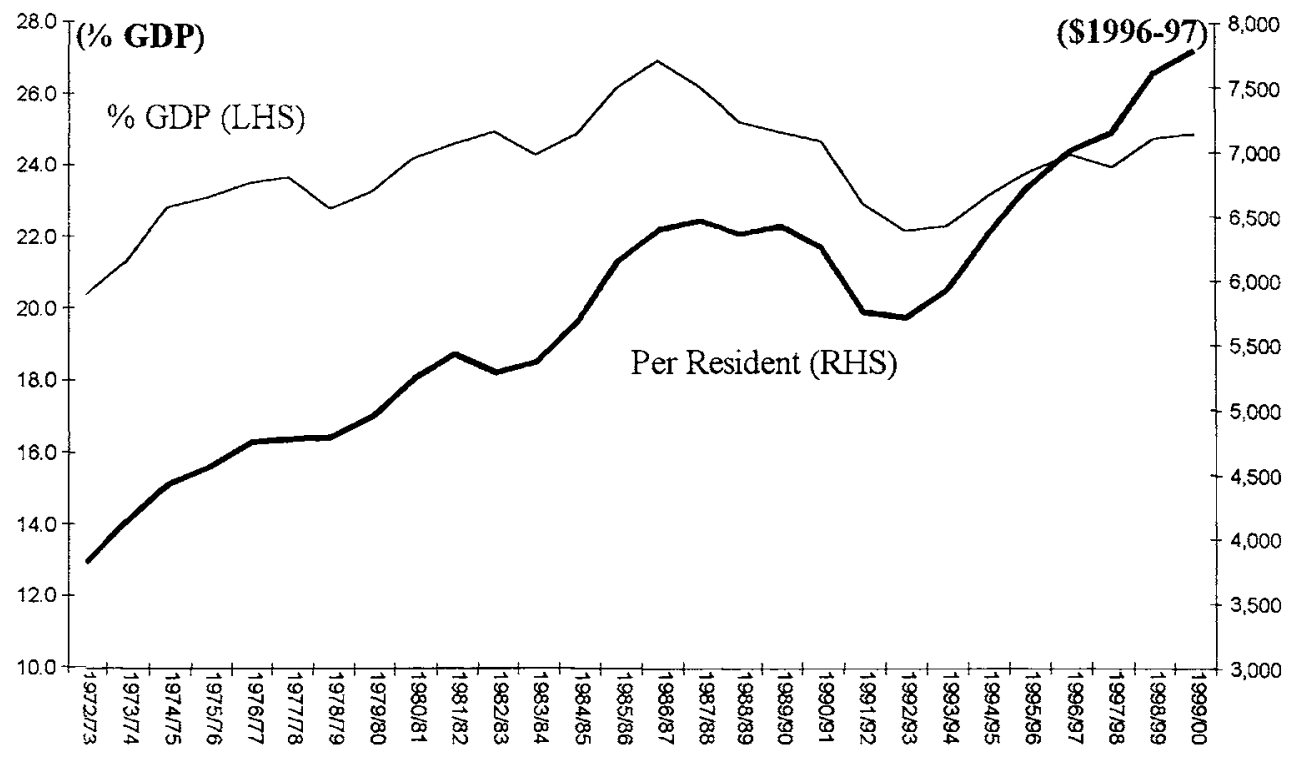

Source: Budget Papers, ABS Australian Demographic Statistics, Australia; National Income, Expenditure and Product; various.

Increased wage dispersion began before the reform period and was primarily driven by increases in the proportion of the population in higher-earning jobs (Wooden 2000), changes in hours worked and a steepening in life-time earning paths. These are not forms of increase in income inequality which should greatly 
excite policy-makers, however mucth it may provide grist for the mill for hose spruiking for (even further increased)) government handouts.

It is particularly ironic to see IKeating's period as Prime Minister as ofe of stringency in public expenditure (Macintyre, 1999a:251) when both Commonwalth outlays and GDP per head grew by 13 per cent under Keating. In line with the long-term deterioration in their fiscall performance, Australian governments spent a total of $\$ 75$ billion more on recurremt expenditure than they took in revenue inder Keating, of which the Commonwealth was responsible for $\$ 43$ billion. Keating is the only postwar Commonwealth Prïme Minister to 'dissave' in every single ore of his budgets - funding non-capital expenditure by borrowing or asset sale making him the worst manager of the Commonwealth's finances in the poswar period and notably worse than Whittlam, who did not do so in any of his budgets (ABS Australian System of National Accounts, various). Here, it should be roted that deficit funding has been a long-term feature of Australian governance. From 1855 until recently, public debt outstanding increased at the end of every financial year (Vamplew, 1987:256). Of course, public debt can go up without non-capital outlays exceeding revenue: all that is required is for some capital expenditure to be funded by borrowing and new borrowing to exceed debt retirement.

\section{The Regulatory Reach of Government}

It is a common claim that the labour market has been deregulated. ${ }^{2}$ There has certainly been significant economic liberalisation of the labour market, though a reregulation push is currently working its way around the ALP-governed States. It is, however, an exaggeration to say the labour market has been deregulated. Though access to other instruments (themselves considerably regulated) has expanded, the award structure still exists while regulation of such things as discrimination, unfair dismissals, occupational health and safety and superannuation has expanded during the reform period. In the real world, the Australian labour market has not been deregulated, merely subject to limited liberalisation from 1993.

Leaving aside the labour market, it is very widespread conventional wisdom that we live in a period of deregulation. This is true, but it has been of a very specific kind and does not mean we live in a less regulated society. Governments have indeed generally abandoned the setting of prices and quantities in markets, and legislative barriers to market entry have been abolished or greatly eased.

Outside these areas, the real Australia is a more regulated society now than it was at the beginning of the reform period. As a rough indication, the eight years 1990 to 1997, a period marked by no great national emergency, saw the Commonwealth Parliament pass more pages of legislation than the period from 1901 to 1980 . While deregulation requires legislation, and issuing operating instructions for the burgeoning welfare state and rewriting of old law into the more wordy 'clear English' explains much of the legislative activity, the total increase

2 For example, Macintyre (1999b) and Manne (1998). 
has been extraordinary, and been accompanied by a considerable increase in the average length of Acts (Figure 4). (There is very little quality control over Parliament's legislative activity.) More to the point, the intrusive ambit of regulation expanded across a range of fields: notably environmental law, health regulation, corporation law, tax law and the aforementioned areas of ancillary employment law.

Figure 4: Commonwealth Parliament: Pages of Legislation Passed

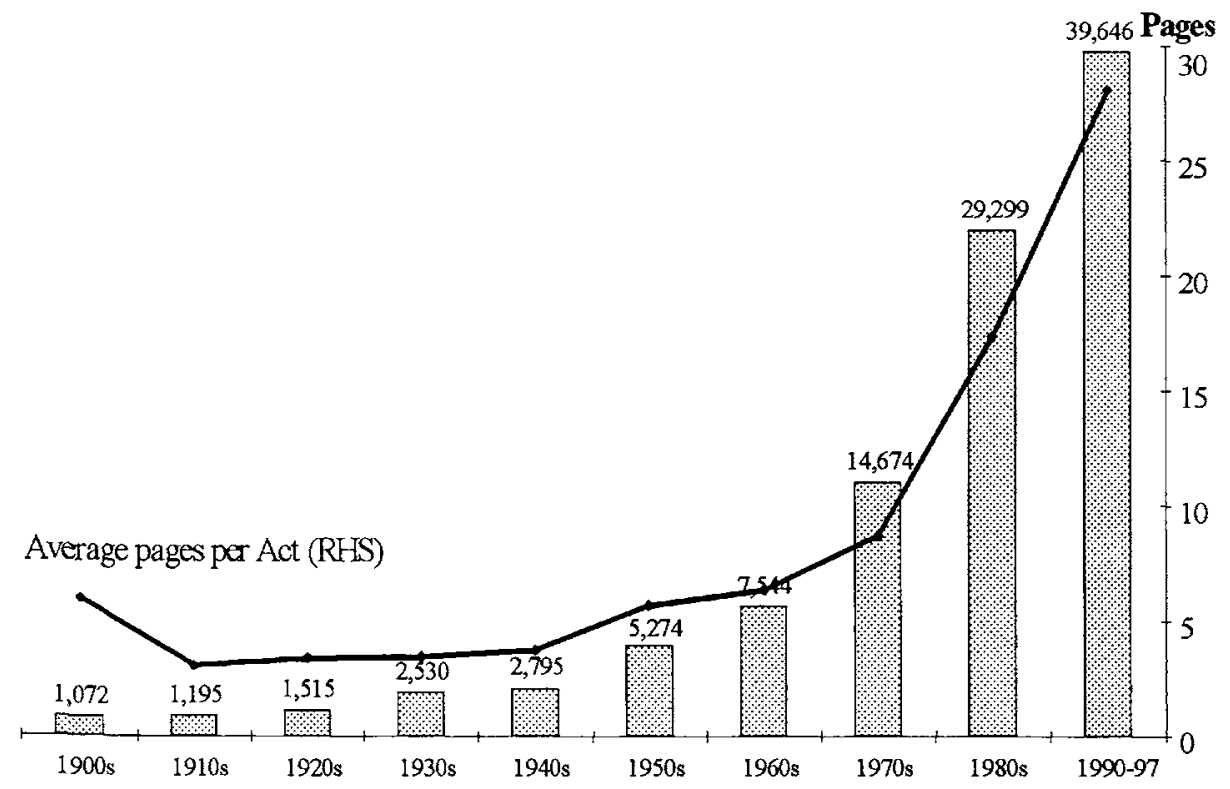

Source: Acts of the Commonwealth.

Nor does the fact that, from May 1978 to November 1999, the number of lawyers or legal professionals more than tripled, from 14,000 to 46,000 , while total employment grew by less than 50 per cent (ABS Microfiche, ABS Labour Force, Australia, November 1999) suggest reduced regulatory reach by government. On the contrary, partly as a result of privatisation but also because of increased regulatory activity, the proportion of the private sector workforce, particularly the professional workforce, engaged in interacting with government has never been so high. The interest of governments in economic efficiency clashes with the interests of many groups in regulatory complexity - government bureaucrats and tribunals building regulatory empires, corporate bureaucrats with an interest in preserving the importance of their special knowledge, employer groups with an interest in selling regulation management services to their members, politicians being seen to 'do something', larger firms raising regulatory costs for smaller competitors, lawyers with an interest in selling their services and so on. The common 
presumption of decreasing levels of regulation makes preserving such special interests easier.

We should not be surprised by the continuing tendency of government to expand. If the role of government is to 'do good' without a strong sense of its capacity to do so efficaciously being limited — and it is not restrained by institutional factors - then there is no real limit on its increase, since there will always be more 'good' for it to do. Wants, being conjurings of the mind, are as unlimited in claims for social justice as anywhere else. Indeed, one of the problems, and appeals, of political delivery is the ability it provides to attempt to avoid the costs of one's claims (Sowell, 1983:246).

\section{Why?}

How do these commentators come to describe a fictional, rather than a real Australia? A simple-minded reliance on media might be one cause. After all, the news generated by the on-going fiscal pressure from an expanding welfare state tends to be about things such as cuts to particular services, acts of deregulation and privatisations. The steady expansion in welfare provision and increased legislative activity is nowhere near as newsworthy. Moreover, since government provision is centralised, adjustments to changes in population distribution and demographics tend to happen suddenly, en masse. Instead of a series of adjustments as one gets with private providers in markets, there is a sudden massive adjustment - a whole range of schools, or coal mines or whatever are closed in one operation.

Furthermore, the specious promise to abolish scarcity in particular goods and services by 'free' provision leads to rationing by queue and funding crunches. The tendency of political provision to be inefficient and provide services of dubious quality also encourages belief in inadequate funding.

The result is a pervasive sense of cutbacks (since those that occur are big and memorable) and inadequate provision (because the services provided are judged to be of poor quality, less than demanded, etc). With many academics and others adding their voices - such as the NGO sector as already noted - the tale of shrinking government becomes the conventional wisdom. That the divorce between conventional wisdom and reality is so large is an indicator of how inadequate of information flows via political mechanisms tend to be.

It takes some effort to look further. For example it should be noted that, in the context of Australia's persistently high current account deficits, the correlation between general government expenditure on health, education and welfare and national saving from $1959-60$ to $1998-99$ is an extraordinarily high -0.92: that Australia is substituting welfare expenditure for saving (both private and public), hence the expansion of the current account deficit in the 1970s.

But to do that then raises some awkward questions about welfare expenditure and its costs. Which may do much to explain the willingness of commentators to wander off into some fictional Australia: commitment to the welfare state is widely seen as a sign of virtue; how much more comforting, therefore, to write about a 
fictional Australia where there is nothing negative to say about the welfare state (except that it is not big enough).

This would also help explain the tendency to fictional definitions of 'economic rationalism'. The term was originally used as a 'trumping' term in favour of economic reform but has come to imply some parochial and ideological madness, unlike the more accurate (and international) 'economic liberalisation'. Professor Macintyre (1999a:239-40) says that economic rationalism

was remarkable not so much for devotees' capacity to incorporate almost every form of human behaviour into its syllogisms as for the assumption that there could be no other form of reason than the logic of the market.

This is in a similar vein to the definition from Michael Pusey (1993:4), that:

Economic rationalism is a doctrine which says that markets and prices are the only reliable means of setting a value on anything and, further, that markets and money can always, at least in principle, deliver better outcomes than states and bureaucracies

In my 11 years in the Canberra bureaucracy, including five in the Parliamentary Library, I never encountered anyone who could be so described by either definition in the public service or among politicians or Ministerial staffers. When Dr Michael Keating, then head of the Department of Prime Minister and Cabinet and econocrat par excellence, was asked at the conference in which Professor Pusey's paper was delivered if he had ever encountered someone in the public service who conformed to Professor Pusey's definition, he equally replied in the negative (Warby, 1993:137-8).

Professor Macintyre (1999a:245) claims that:

by conceding the economic arguments of the New Right, Labor still hoped to escape its ruthless repudiation of responsibility for the weak and vulnerable

which also manages not to describe people in the real world. Milton Friedman, for example, has been a considerable intellectual innovator in welfare (negative income tax) and education policy (vouchers), while Hayek always conceded a safety net role for government. President Reagan in the US and Prime Minister Thatcher in the UK both presided over increases in welfare spending.

This commitment to the fictional includes the use of the term 'neo-liberal' - a term that, as far as I am aware, no-one uses to describe themselves - and which, given the unbroken continuation of the classical liberal intellectual tradition, is particularly inappropriate. One wonders whether the term is a sign of the difficulties recent trends generate to those who still, in one form or another, want to think that history rightfully should be moving in a socialist direction. One of the 
more amusing habits of many devotees of this fictional universe is the habit of not quoting reformers directly, but relying on hostile summaries - as if one would be polluted by direct quotation, and if, by such indirect citation, one can show appropriate respect to those brave souls who have so risked such contamination. More direct examination of what reform advocates have written, and more consultation with colleagues in economic departments (even those who are economic liberals) would make avoidance of error more likely.

It is a commonplace of economic thought that private action will tend to underprovide public goods. Unfortunately, attention to the public good is itself a public good - an activity whose costs are personal but whose benefits are dispersed - and so is underprovided. Further, it is hardly surprising that many contributions to public debate, and to politics, seek to promote private goods. Much of the phenomenon known as 'political correctness' (analysis of which should distinguish between the attempt to develop a new sense of public courtesy and the attempt to claim morally trumping standing on the basis of adhering to certain propositions) seeks to generate to its adherents the private good of increased status (including protecting such status claims by increasing the costs of participation in public debate for those of contrary views). There is more than a little statusseeking among the commentators resorting to descriptions of a fictional Australia. This seems to be mixed in with an apparent dislike by many of the political scientists, sociologists and historians who have criticised 'economic rationalism' of the influence of economics and economists - thus, Stewart comments that 'Michael Pusey has documented the extraordinary hold which ways of thinking dominated by economics had on the Australian federal bureaucracy in the 1980s' (Stewart, 1994:272).

This resort to a fictional universe may be a useful device for denying any rationality to the reformers, and in shielding the beliefs of its devotees from dealing with various difficulties, but it cannot pass as genuine scholarship. It has two invidious effects that even its practitioners should consider. First, by failing to deal with the issues policy makers actually have to deal with, it deals the critics out of the serious policy debate. Second, since most of those so indulging are employed by universities, it provides a good basis for arguing that universities are overfunded. After all, providing accurate scholarship about the world around us is something we might all benefit from. Self-indulgent propagandising about a fictional Australia, on the other hand, is undoubtedly a waste of public funds.

\section{References}

ACIRRT (1999), Australia at Work: Just Managing?, Prentice Hall, Sydney.

Buchanan, J. (1990), 'Socialism is Dead, but Leviathan Lives On', Seventh Annual John Boynthon Lecture, Sheraton Wentworth, Sydney, 27 March (http://www.cis.org.au).

Carroll, J. (1999), 'Australian electorate strikes back', Australian Financial Review, 14 December: 19. 
Cor, E. (1995), 'A Truly Civil Society', 1995 Boyer Lectures, ABC Books, Sydney.

Hading, A. (1997), 'The Suffering Middle: Trends in Income Inequality in Australia 19\$2 to 1993-94', NATSEM, University of Canberra (Discussion Paper No. 21) (htp://www.natsem.canberra.edu.aw/).

Mxintyre, S. (1999a), A Concise History of Australia, Cambridge University Press, Mabourne.

Macintyre, S. (1999b), 'It's time Labor got back to the job', Australian Financial Review, 12 Nevember:45.

Manre, R (1998), 'So important, so dull', The Age, 14 September:15.

Naton, A. (2000), 'The Answer isn't Public Funding', The Age, 1 August:13.

Pusey, M. (1993), 'Reclaiming the Middle Ground ... from New Right Economic Raionalism', paper delivered at 'Economic Rationalism? Economic Policies for the 1990;' conference held at the University of Melbourne, 15 February.

Sowell, T. (1983), The Economics and Politics of Race: An International Perspective, Quill. New York.

Stcwart, J. (1994), The Lie of the Level Playing Field: Industry Policy and Australia's Future, Text Publishing, Melbourne.

Vamplew, W. (1987), Australians: Historical Statistics, Fairfax, Syme \& Weldon Associates, Sydney.

Warby, M. (1993), 'Scapegoating and Moral Panic: Political Reality and Public Policy Versus Anti-rationalism', pp. 132-142 in James, C., C. Jones and A. Norton (eds), A Defence of Economic Rationalism, Allen and Unwin, Sydney.

Warby, M. (1998), 'Equality, Justice and Sustainability: the Failing Logic of the Welfare State', pp. 81-96 in Goldsmith, M. (ed.) Social Justice: Fraud or Fair Go?, Menzies Research Centre, Sydney.

Warby, M. and M. Nahan (1998), From Workfare State to Transfer State: Where We Were and Why We've Changed, IPA Backgrounder, Melbourne.

Wooden, M. (2000), 'Industrial Relations Reform: Do the Critics Have a Case?', IPA Review 52(3):14-15.

The author would like to thank Franco Papandrea and two anonymous referees for their helpful comments. 